\title{
APLIKASI LOCATION BASED SERVICE UNTUK INFORMASI KULINER DI YOGYAKARTA
}

\author{
Erviana Devie ${ }^{1}$, Edy Winarno ${ }^{2}$ \\ ${ }^{1,2}$ Program Studi Teknik Informatika, Fakultas Teknologi Informasi, Universitas Stikubank

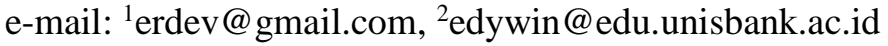

\begin{abstract}
Abstrak
Aplikasi Location Based Service (LBS) banyak dikembangkan karena mempunyai kemanfaatan yang sangat penting untuk berbagai hal, tak terkecuali untuk informasi kuliner. Dalam penelitian ini dibuat sebuah aplikasi kuliner dengan menggunakan metode location based service untuk mendapatkan suatu titik lokasi pada aplikasi, aplikasi yang dirancang untuk mempermudah pengguna mengunjungi berbagai macam kuliner saat berkunjung ke yogyakarta dengan menampilkan estimasi jarak dari posisi awal penggguna ke tempat tujuan. Penelitian ini memanfaatkan global positioning system pada perangkat android. Pada perancangan ini digunakan rumus haversine untuk menghitung jarak tempuh pengguna dari posisi awal menuju lokasi tujuan secara manual. Hasil dari pengujian yang dilakukan pada salah satu data menunjukan selisih dari jarak tempuh sebanyak $\pm 40 \mathrm{~km}$.
\end{abstract}

Kata Kunci: LBS, Haversine, kuliner

\section{PENDAHULUAN}

Perkembangan teknologi yang semakin maju dan mampu memberikan informasi - informasi tentang segala hal seperti lokasi wisata, lokasi kuliner, dll. Cara untuk memberitahukan informasi tersebut melalui sebuah aplikasi mobile yang mudah di dapatkan melalui play store maupun ios, semakin majunya teknologi para developer aplikasi saling bersaing untuk membuat sebuah aplikasi, dalam hal ini aplikasi yang mudah di gunakan orang dari segala umur dan menfaatkan keadaan seperti lokasi kuliner karena setiap orang jika pergi ketempat wisata atau ke suatu daerah yang dicari adalah kuliner. Setiap kuliner didaerah mempunyai makanan khas serta tempat yang legendaris dari setiap tempat

Menerapkan metode LBS ( location Based Service ) untuk menentukan titik lokasi yang sudah dipilih. Adapun tujuan dari pengembangan ini adalah untuk mengetahui estimasi jarak tempuh dari posisi awal menuju lokasi tujuan

Pada penelitian mengenai Aplikasi Pencarian Tempat Makan Menggunakan Location Based Service pada Android [1] . Metode yang digunakan dalam penelitian ini menggunakan Location Based Service. Kelebihan dari aplikasi ini dapat memberikan informasi mengenai rumah makan terdekat dan dapat digunakan dalam sistem android

Pada penelitian mengenai Location Based Service For Presence System Using Haversine Method [2]. Metode Haversine diterapkan pada perhitungan jarak untuk sistem kehadiran berdasarkan jarak lokasi. Deteksi ini dilakukan dengan melihat titik terdekat dari titik pusat yang telah ditentukan

Pada penelitian mengenai Pengembangan Sistem Penunjang Keputusan Pemilihan Tempat Kuliner dengan Metode AHP dan SAW [3]. Kelebihan dari aplikasi ini untuk memudahkan pengguna dalam menentukan restoran mana yang sesuai dengan berdasarkan kriteria yang diinputkan

Membuat penelitian mengenai sistem informasi geografis berbasis android untuk parwisata di daerah Magelang [4]. Sistem ini dibangun menggunakan software eclipse sebagai editor untuk coding android. Kelebihan dari aplikasi ini dapat melakukan pencarian tempat wisata berdasarkan kategori, nama tempat wisata, jarak terdekat, dan berdasarkan daerah.

Membuat penelitian mengenai pengembangan sistem pakar rekomendasi kuliner di kota malang berbasis android dengan menggunakan metode Certainty Faktor [5]. Kelebihan dari aplikasi ini 
memberikan informasi beberapa rumah makan yang sesuai dengan apa yang diinginkan. Kekurangan dari aplikasi ini hanya mengandalkan rekomendasi pengetahuan dari pakar

Membuat penelitian mengenai aplikasi pencarian rute perguruan tinggi berbasis android menggunakan Location Based Service di kota Semarang [6]. Metode yang digunakan dalam penelitian ini menggunakan Location Based Service. Kelebihan dari aplikasi ini memberikan informasi mengenai lokasi dan rute untuk menuju perguruan tinggi yang ada di kota semarang.

Membuat penelitian mengenai analisis dan perancangan aplikasi layanan informasi wisata budaya Yogyakarta berbasis Mobile Web dan Location Based Service secara kolaboratif [7]. Metode yang digunakan dalam penelitian ini menggunakan Location Based Service. Kelebihan dari aplikasi ini dapat diakses melalui mobile tanpa terikat platform dari gadget yang digunakan

Membuat penelitian mengenai wisata kuliner Solo berdasarkan Metode User Centered Design berbasis web [8]. Metode UCD dipilih untuk memudahkan pengguna dalam menggunakan fasilitas yang ada dalam web, sehingga tercipta aplikasi yang userfriendly, yaitu mudah digunakan dan tidak membingungkan pengguna. Kelebihan dari aplikasi ini dapat memberikan informasi kepada masyarakat ataupun wisatawan serta terdapat menu kritik dan saran sehingga pengunjung web dapat saling bertukar informasi dari kritikan tersebut dapat dijadikan acuan

Aplikasi informasi kuliner yang digunakan sekarang menggunakan location based service yang mampu menampilkan rute jalan dari sebuah maps, sistem ini juga mampu menampilkan jarak tempuh dari lokasi awal pengguna menuju ke tempat lokasi yang dituju . Tampilan sistem proses LBS dapat dilihat pada Gambar 1.

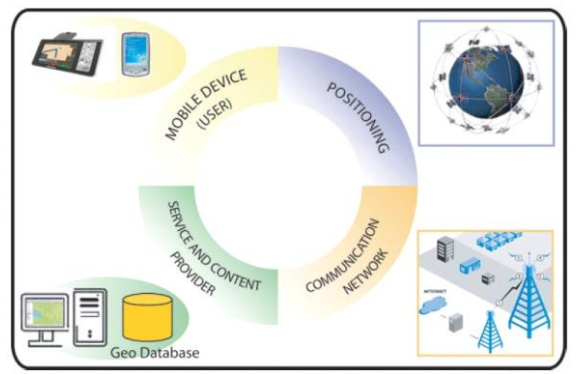

Gambar 1. Sistem Proses LBS

\section{METODE PENELITIAN}

Aplikasi informasi kuliner Yogyakarta membutuhkan sebuah rumus untuk menghitung jarak tempuh pengguna dengan metode Location Based Service tersebut dalam mengetahui jarak yang akan dilalui dari titik awal pengguna ke tempat yang dituju. Perhitungan secara manual menggunakan rumus haversine dengan mengetahui titik awal dari pengguna dan titik tujuan.

Masalah utama yang terkadang muncul pada metode location based service adalah di antaranya, tidak adanya koneksi internet untuk menampilkan lokasi pada maps yang akan membantu pengguna menuju lokasi. Dengan hal tersebut Metode yang digunakan pada aplikasi ini menggunakan metode location based service yang yang terhubung dengan internet, metode location based service memiliki beberapa komponen di antaranya mobile devices, communication network, position component, dan service and content provider.

\section{- Location Based Service}

Metode location based service merupakan salah satu metode layanan berbasis lokasi untuk mengetahui rute perjalanan, yang memberikan hasil dengan tingkat keakuratan yang cukup tinggi serta dapat memberikan informasi lokasi. Layanan ini menggunakan teknologi global positioning service (GPS) dan cell-based location dari Google. Selain itu, LBS tersebut terdiri dari beberapa komponen di antaranya mobile devices berfungsi sebagai alat bantu (tool) bagi pengguna untuk meminta informasi, communication network berfungsi sebagai jalur penghubung yang dapat mengirimkan data-data yang dikirim oleh pengguna dari piranti mobile-nya untuk kemudian dikirimkan ke penyedia layanan dan kemudian hasil permintaan tersebut dikirimkan kembali oleh 
penyedia layanan kepada pengguna, position component, dan service and content provider penyedia layanan yang menyediakan layanan berbeda ke pengguna seperti pencarian rute, kalkulasi posisi, dan lainnya. Sederhananya, dengan layanan LBS kita dapat mengetahui posisi dimana kita berada. Langkah awal yang dilakukan oleh metode Location Based Service dalam pencarian lokasi yaitu mengaktifkan fungsi pencarian dimana posisi pengguna yang ada diponsel diperoleh dari positioning service pada GPS. Setelah itu perangkat ponsel akan mengirim informasi yang berisi tujuan untuk mencari dan mengirimkan posisi melalui jaringan komunikasi ke gateway. Kemudian, service menganalisis pesan dan memutuskan informasi tambahan pencarian dan posisi pengguna dan selanjutnya service akan menemukan bahwa informasi mengenai jalan, jarak dan memeriksa apakah tujuan tersebut dapat dicapai dan akan ditampilkan kepada pengguna dalam bentuk peta.

- Global Positioning System

Sistem navigasi yang menggunakan satelit yang didesain agar dapat menyediakan posisi secara instan, kecepatan dan informasi waktu di hampir semua tempat di muka bumi, setiap saat dan dalam kondisi cuaca apapun. System ini digunakan untuk menentukan posisi pada permukaan bumi dengan bantuan sinkronisasi sinyal satelit. Sistem kerja GPS dengan menstransmisikan sinyal dari satelit ke perangkat GPS ataupun smartphone yang sudah memiliki fitur GPS. GPS membutuhkan transmisidari 3 satelit untuk mendapatkan informasi dua dimensi (lintang dan bujur), dan 4 satelit untuk 3 dimensi (lintang, bujur dan ketinggian).

\section{- Rumus Haversine}

Rumus haversine merupakan persamaan penting pada navigasi, memberikan jarak lingkaran besar antara dua titik pada permukaan bola (bumi) berdasarkan bujur dan lintang dengan jari-jari $\mathrm{R}$ 6.367 dan untuk menghitung jarak tempuh pada Location Based Service secara manual dengan mengetahui longitude dan latitude pada Maps, berikut rumus haversine :

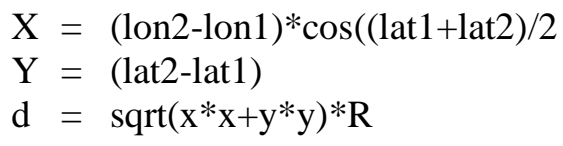

Keterangan:

$\mathrm{x}=$ Longitude (Lintang)

$\mathrm{y}=$ Lattitude (Bujur)

$\mathrm{d}=$ Jarak

$\mathrm{R}=$ Radius Bumi $=6371 \mathrm{~km}$

1 derajat $=0.0174532925$ radian

\section{HASIL DAN PEMBAHASAN}

\subsection{Pembahasan}

Aplikasi informasi kuliner menggunakan metode location based service menggunakan beberapa tahap yang dibangun dengan susunan struktur dimana pengguna akan masuk kelayar utama dan memilih ikon pada pojok atas dan akan muncul tampilan jenis makanan, selebihnya gambaran dari aplikasi dapat dilihat pada Gambar 2

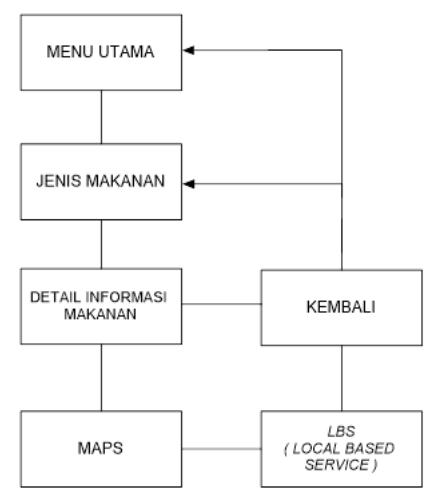

Gambar 2. Struktur Program Aplikasi 
Dari hasil penelitian ini aplikasi informasi kuliner Yogyakarta sistem penghitung jumlah wajah hanya terdapat 4 tahapan pada aplikasi informasi kuliner. Tahapan pertama merupakan tampilan dari Menu Utama tampilan tersebut dapat dilihat pada Gambar 3.

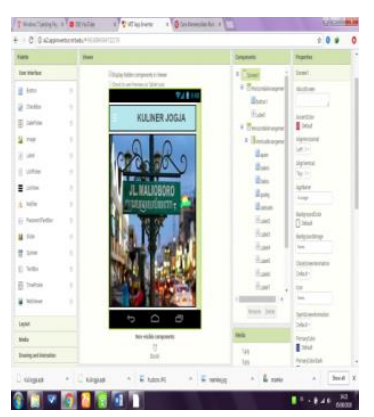

Gambar 3. Tampilan Menu utama

Dalam tampilan menu utama merupakan proses awal berhasilnya program aplikasi dan proses tampilan selanjutnya ketika pengguna memilih ikon pada pojok kiri atas maka akan muncul sebuah menu makanan, tampilan dari menu makanan dapat dilihat pada gambar 4.

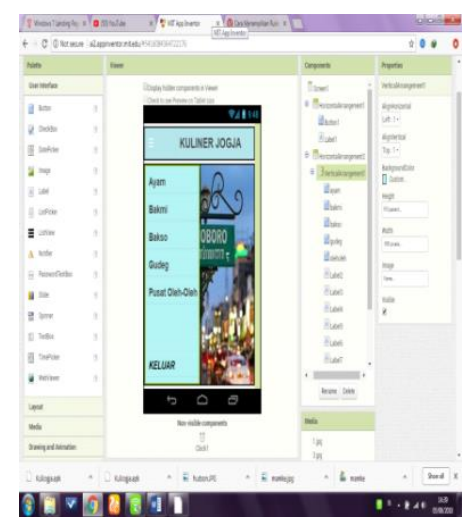

Gambar 4. Tampilan Menu Makanan

Proses dari tampilan menu jenis makanan merupakan tampilan setelah pengguna memilih salah satu dari menu makanan. Terdapat beberapa jenis menu makanan dalam tampilan ini, tampilan menu jenis makanantersebut dapat dilihat pada Gambar 5.

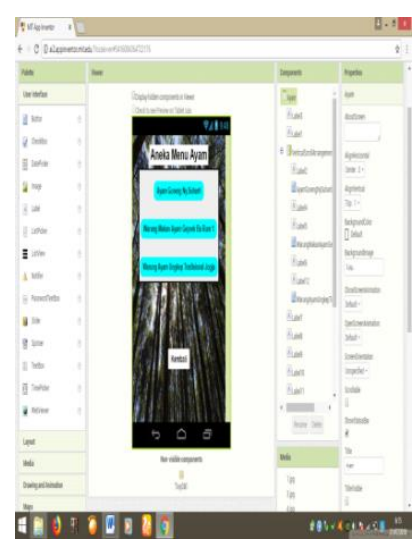

Gambar 5. Tampilan Menu Jenis Makanan 


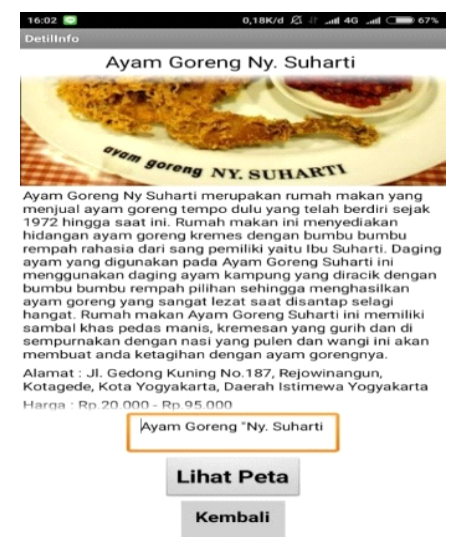

Gambar 6. Tampilan Informasi Makanan

Pada tampilan informasi makanan terdapat informasi tentang nama makanan, gambaran makanan tersebut atau sejarah, harga, alamat, no.telp, jam operasional serta perintah untuk menampilkan peta petunjuk jalan. Tampilan informasi makanan dapat dilihat pada Gambar 6 .

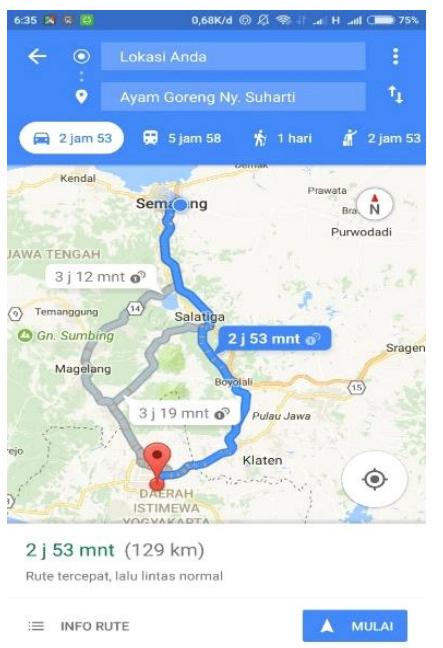

Gambar 7. Tampilan Peta Lokasi

Tahapan terakhir dari aplikasi informasi kuliner ini merupakan tampilan peta lokasi yaitu menampilkan rute perjalanan dari titik awal pengguna ke tempat tujuan dan terdapat jarak tempuh perjalanan. Tampilan peta lokasi dapat dilihat pada Gambar 7.

\subsection{Pengujian}

Pengujian akurasi jarak tempuh sebelumnya dilakukan dengan data dari beberapa jenis menu makanan yang kemudian akan ditampilkan pada tampilan Maps dan dihitung secara manual menggunakan rumus haversine. Hasil dari jarak tempuh dengan menggunakan metode location based service dan menggunakan rumus dapat dilihat pada Tabel 1.

Tabel 1. Tabel akurasi jarak tempuh

\begin{tabular}{|c|c|c|c|} 
No & Gambar & Jarak sebelumnya & Jarak sebenarnya \\
\hline 1 & Gambar 1 & $131 \mathrm{~km}$ & $84,6 \mathrm{~km}$ \\
2 & Gambar 2 & $121 \mathrm{~km}$ & $77 \mathrm{~km}$ \\
\hline 3 & Gambar 3 & $136 \mathrm{~km}$ & $91 \mathrm{~km}$ \\
4 & Gambar 4 & $124 \mathrm{~km}$ & $85,7 \mathrm{~km}$ \\
\hline 5 & Gambar 5 & $130 \mathrm{~km}$ & $85 \mathrm{~km}$ \\
\hline
\end{tabular}

Dari proses penghitungan jarak tempuh pada data yang diambil dari beberapa menu jenis makanan yang dilakukan dengan metode location based service dan menggunakan rumus haversine 
yang dihitung secara manual, memiliki selisih jarak tempuh yang berbeda dari jarak tempuh menggunakan location based service, hasil dari perhitungan menggunakan location based service dengan menggunakan rumus memilki selisih jarak tempuh sekitar $\pm 40 \mathrm{~km}$.

\section{KESIMPULAN}

Berdasarkan hasil implementasi yang telah dilakukan dalam pembuatan program "Pengembangan Aplikasi Informasi Kuliner Yogyakarta Menggunakan Metode Location Based Service", dapat ditarik beberapa kesimpulan dan saran dari penelitian ini. Kesimpulan yang dapat diambil dari penelitian pengembangan aplikasi informasi kuliner yogyakarta menggunakan metode location based service yaitu:

- Terciptanya suatu aplikasi untuk memudahkan pengguna mengetahui informasi lokasi kuliner yang ada di kota Yogyakarta.

- Pemrograman aplikasi ini dibuat menggunakan metode Location Based Service untuk mengetahui jarak tempuh dari posisi pengguna ke tempat tujuan.

- Aplikasi informasi kuliner yogyakarta dibuat dengan menggunakan App Inventor.

- Pengguna akan mendapatkan informasi berupa gambar makanan, gambaran makanan atau sejarah, alamat, harga, nomor telepon, jam operasional serta rute jalan menuju lokasi tujuan yang akan ditampilkan pada Google Maps.

- Aplikasi ini menggunakan akses internet untuk mengetahui petunjuk arah ke lokasi tujuan dari posisi pengguna.

- Perhitungan menggunakan rumus haversine selalu lebih kecil dari sistem dikarenakan rumus haversine menggunakan perhitungan udara sedangkan sistem menggunakan perhitungan arah rute jalan.

Beberapa saran yang dapat digunakan untuk mengembangkan aplikasi informasi kuliner menjadi lebih baik selanjutnya yaitu:

- Penambahan fitur beberapa menu makanan yang ada di sekitar Yogyakarta.

- Mengganti tampilan apikasi kuliner menjadi lebih baik yang berbeda dari aplikasi sebelumnya.

- Program aplikasi dapat diubah menjadi suatu aplikasi selain aplikasi informasi kuliner seperti aplikasi wisata, toko souvenir, dll.

\section{DAFTAR PUSTAKA}

[1] Astradanta, M., Wirawan, I.M.A., dan Arthana, I.K.R., (2016), Pengembangan Sistem Penunjang Keputusan Pemilihan Tempat Kuliner Dengan Menggunakan Metode AHP Dan SAW, Kumpulan Artikel Mahasiswa Pendidikan Teknik Informatika (KARMAPATI) Vol: 5, No:2, Universitas Pendidikan Ganesha, Bali

[2] Julianto., Dkk (2014), Rancang Bangun Aplikasi Layanan Informasi Wisata Budaya Yogyakarta Berbasis Mobile Web Dan Location Based Service Secara Kolaboratif, Universitas Atma Jaya, Yogyakarta

[3] Nugroho, S.C., Nurhayati, O.D., dan Widianto, E.D., (2016), Aplikasi Pencarian Rute Perguruan Tinggi Berbasis Android Menggunakan Location Based Service (Lbs) Di Kota Semarang, Universitas Diponegoro, Semarang

[4] Oktaviani, I., Anjar, D., dan Putri, A., (2016), Wisata Kuliner Solo Berdasarkan Metode User Centered Design Berbasis Web, Hotelier Journal Politeknik Indonusa Surakarta Vol. 1 Nomor 3, STMIK Duta Bangsa, Surakarta

[5] Pratami, R.D., Bettiza, M dan Kurniawan. H., (2014), Aplikasi Pencarian Tempat Makan Menggunakan Location Based Service Pada Android, Universitas Maritim Raja Ali Haji, Tanjungpinang 
[6] Pratama, S.A., Syaifudin, Y.W dan Harijanto, B., (2016), Pengembangan Sistem Pakar Rekomendasi Kuliner Di Kota Malang Berbasis Android Menggunakan Metode Certainty Factor, Politeknik Negeri Malang, Malang

[7] Winarno, E., Hadikurniawati,W dan Rosso, R.N., (2017), Location Based Service For Presence System Using Haversine Method, DOI: 10.1109/INNOCIT. 2017.8319153

[8] Yuwono, B., Aribowo, A.S., dan Setyawan, F.A., (2015), Sistem Informasi Geografis Berbasis Android Untuk Pariwisata Di Daerah Magelang, UPN Veteran, Yogyakarta 